\title{
Evaluation of the extract of Zeyheria tuberculosa with a view to products for wound healing ${ }^{1}$
}

\author{
Patrícia de Albuquerque Sarmento ${ }^{2}$ \\ Terezinha da Rocha Ataíde ${ }^{3}$ \\ Ana Paula Fernandes Barbosa ${ }^{4}$ \\ João Xavier de Araújo-Júnior ${ }^{5}$ \\ Ingrid Martins Leite Lúcio ${ }^{6}$ \\ Maria Lysete de Assis Bastos ${ }^{6}$
}

Objectives: to evaluate the antimicrobial, cytotoxic and healing activities of the ethanolic extract of the stems of $Z$. tuberculosa via topical use and/or oral ingestion. Method: antimicrobial assays in vitro using the disk diffusion method, the Artemia salina toxicity test, and in vivo assays with Wistar rats. From these was collected clinical, histological and biochemical data for evaluating the healing process. Results: in vitro antimicrobial testing showed activity in relation to Streptococcus pyogenes, Staphylococcus aureus and Staphylococcus epidermidis, with zones of inhibition of 18,14 and $10 \mathrm{~mm}$, respectively. The best minimum inhibitory concentration was $62.5 \mu \mathrm{g} / \mathrm{ml}$ for S. aureus, this bacteria being chosen for the in vitro assays. Animals treated with the ointments with the extract of $Z$. tuberculosa showed the best results in the reduction of the wound diameter, data confirmed by the presence of re-epithelialization in the histological samples. Conclusion: the extract was shown to be promising for the continuation of studies which may identify the active ingredients responsible for the pharmacological activity and its mechanism of action in the process of wound healing, so as to develop a product which may be used as an alternate means in the repair of infected cutaneous wounds.

Descriptors: Wound Healing; Biological Assay; Vegetal Extracts; Microbial Sensitivity Tests.

\footnotetext{
${ }^{1}$ Paper extracted from master's thesis "Evaluation of antimicrobial activity and cytotoxicity in vitro and in vivo of crude ethanol extract of the stem Zeyheria tuberculosis (vell) Bur. (Bignoniaceae): perspective of a supplement for wound healing", presented to Faculdade de Nutrição, Universidade Federal de Alagoas, Maceió, AL, Brazil. Supported by Conselho Nacional de Desenvolvimento Científico e Tecnológico (CNPq), process \# 474023/2010-9.

${ }^{2}$ Doctoral student, Rede do Nordeste de Biotecnologia, Carpina, PE, Brazil. Assitant Professor, Escola de Enfermagem e Farmácia, Universidade Federal de Alagoas, Maceió, AL, Brazil.

${ }_{3}^{3} \mathrm{PhD}$, Associate Professor, Faculdade de Nutrição, Universidade Federal de Alagoas, Maceió, AL, Brazil.

${ }^{4} \mathrm{PhD}$, Adjunct Professor, Faculdade de Medicina, Universidade Federal de Alagoas, Maceió, AL, Brazil.

${ }^{5} \mathrm{PhD}$, Associate Professor, Escola de Enfermagem e Farmácia, Universidade Federal de Alagoas, Maceió, AL, Brazil.

${ }^{6} \mathrm{PhD}$, Adjunct Professor, Escola de Enfermagem e Farmácia, Universidade Federal de Alagoas, Maceió, AL, Brazil.
}

Corresponding Author:

Patrícia de Albuquerque Sarmento

Universidade Federal de Alagoas. Escola de Enfermagem e Farmácia

Rod. 104 Norte, Km 96

Bairro: Tabuleiro do Martins

CEP: 57072-970, Maceió, AL, Brasil

E-mail: enfpatricia@hotmail.com
Copyright $\odot 2014$ Revista Latino-Americana de Enfermagem This is an Open Access article distributed under the terms of the Creative Commons Attribution Non-Commercial License (CC BY-NC).

This license lets others distribute, remix, tweak, and build upon your work non-commercially, and although their new works must also acknowledge you and be non-commercial, they don't have to license their derivative works on the same terms. 


\section{Introduction}

The process of the scarring of wounds involves a cascade of complex events, involving the inflammatory, proliferative and remodeling phases. These phases overlap continuously and temporally. The treatment's success is directly related to the choice of the correct substance to act in each of these stages. However, when there is infection in the wound bed it is necessary to eliminate the infectious process in order to continue with the therapy ${ }^{(1)}$.

In spite of the allopathic hegemony and the predominance of synthetic substances for local and systemic use in wound treatment, one may observe a growing interest in naturalist alternatives, which promote the healing of the wounds. If the therapeutic use of medicinal plants in the care was previously was marginalized by the health institutions, today it is overcoming these barriers to be legitimized in this environment ${ }^{(2)}$.

Brazil is one of the countries which have so-called megadiversity, and possesses approximately 120,000 species of plant. Only $10 \%$ of these species, however, have been studied from the phytochemical and biological viewpoint $^{(3)}$. The plants of the Bignoniaceae family, in which the species Zeyheria tuberculosa (Z. tuberculosa) is included, are considered important because among their constituents they present bio-active ingredients and various pharmacological activities, and are included in traditional medicine for treatment of conditions such as cancer, snakebite, skin diseases, gastro-intestinal disorders, respiratory tract disorders, gynecological conditions, hepatic disorders, epilepsy, cholera, pain, urinary problems, malaria, cardiac problems, and sexually transmitted diseases ${ }^{(3-4)}$.

The perspective of use of the extract of the stems of $Z$. tuberculosa arose from a study(5) in which was proven its antimicrobial activity regarding Staphylococcus aureus and Candida albicans, in in vitro bioassays. That research also isolated and identified four flavonoids, three of which were described for the first time for this genus. The flavonoids are compounds found in some foods, barks, stems, roots, stalks, and flowers, possessing innumerable pharmacological activities, such as anti-oxidants, antimicrobials, antiinflammatories, analgesics, vasodilators, wound-healing and regenerating cartilage and bone ${ }^{(5-6)}$. With the objective of extending the possibilities for therapeutic resources for the treatment of cutaneous wounds, based on experimental research, this study proposes to evaluate the in vitro antimicrobial and in vitro woundhealing activity of the raw ethanolic extract of the stems of $Z$. tuberculosa by topical and/or oral means.

\section{Method}

\section{The plant and the preparation of the extracts}

The plant species Zeyheria tuberculosa (Vell.) Bur. (Bignoniaceae) was collected by the research group and identified by the Institute for the Environment of the State of Alagoas (IMA), where the exsiccata was deposited under number 23,819.

For the preparation of the extract, the stem was dried at ambient temperature, ground, and placed in ethanol $90 \%$. After 15 days, the solvent was evaporated in a rotary evaporator, under vacuum, at a maximum temperature of $45^{\circ} \mathrm{C}$, until it reached a constant volume. This process of rotary evaporation took place through three cycles, until a clear residue was obtained, which remained exposed in a fume hood until all the solvent contained had volatilized and the raw concentrated extract was obtained.

Evaluation of the in vitro antimicrobial activity and the Determination of the minimum inhibitory concentration (MIC)

The antimicrobial activity of the extract of the stem was tested in triplicate, by the disk diffusion method(7), using bacterial and fungal strains standardized and distributed by the American Type Cell Collection (ATCC). The bacterial strains tested were Streptococcus pyogenes (ATCC 19615), Staphylococcus aureus (ATCC 25923), Staphylococcus epidermidis (ATCC 12228), Pseudomonas aeruginosa (ATCC 27853), Proteus mirabilis (ATCC 49565), Klebsiella pneumoniae (ATCC 31488) and Escherichia coli (ATCC 14942). As a fungal strain, Candida albicans (ATCC 10231) was tested. The minimum inhibitory concentration (MIC) was determined from the sample which presented activity and was chosen for continuation of the study, the MIC being defined based on serial dilutions of the active extract. The experiments were undertaken in triplicate.

\section{Toxicity for Artemia salina Leach (TAS)}

The bioassay with Artemia salina was undertaken in accordance with the literature(5). Artemia salina $L$. is a microcrustacean which can be used in the laboratory in preliminary bioassays to determine the toxicity of extracts and products of natural origin with biological 
action potential. The test is carried out with second instar larvae (nauplii), extracts being considered toxic if they induce mortality greater than or equal to $30 \%$.

\section{Experimental animals or groups}

The in vitro assays were undertaken with 24 adult male rats (Rattus norvegicus albinus - Wistar strain), respecting the Ethical Principles in Animal Experimentation. The study was approved by the Research Ethics Committee of the Federal University of Alagoas (No 009880/2009-77).

The rats were weighed and separated by the probabilistic method of random sampling into six groups $(n=4)$, identified based on the therapy: Positive Control (PC); Negative Control (NC); Topical Extract (TE); Topical and Oral Extract (TOE); Oral Extract (OE) and Vehicle Control (VC). The animals were kept in polyethylene cages, one animal in each cage, each lined with sawdust, in a photoperiod of 12 hours of light and darkness, with minimal noise, and at an ambient temperature of $21 \pm 1^{\circ} \mathrm{C}$, maintained by air conditioning. The animals were fed with commercial feed (Labina ${ }^{\circledR}$, Purina, Brasil), with monitoring of the ingestion, and water "ad libitum".

\section{Ointments for topical use}

The ointments used in this experiment were prepared by a pharmacist and all were produced from a non-ionic base without preservatives. For the PC, $0.1 \%$ gentamycin was added to the above-mentioned base, in the standard concentration for use with humans. In the
TE and TOE groups, 5\% of the extract was added to the non-ionic base, and for the NC and OE groups, the nonionic base alone was used.

\section{Extract for oral use}

A tincture was prepared with the raw ethanolic extract of the stem of $Z$. tuberculosa, in the concentration of $1 \mathrm{mg} / \mathrm{ml}$, a value determined based on the results of the MIC and the TAS to be added to the food of the animals in groups $T O E$ and $O E$, which received the extract orally.

$1 \mathrm{~mL}$ of tincture was added to each pellet of feed in these groups, and after 24 hours of evaporation of the ethanol, in a drying oven at a temperature of $25^{\circ} \mathrm{C}$, was offered to the animals daily, with their ingestion being monitored.

\section{Biological assays for evaluation of wound healing and antimicrobial activity in vivo}

The body weight of each animal was ascertained for the monitoring and calculation of the anesthesia. Sodium thiopental was used at $40 \mathrm{mg} / \mathrm{Kg}$ of weight, via intraperitoneal injection. Following this, their temperatures were verified rectally, epilation was undertaken of their backs, skin antisepsis with performed with chlorhexidine $2 \%$, and, with a metal punch, four $12 \mathrm{~mm}$ para-vertebral excision wounds were made, based on the medial dorsal line, down to the level of the aponeurotic tissue, as shown in Figure 1.

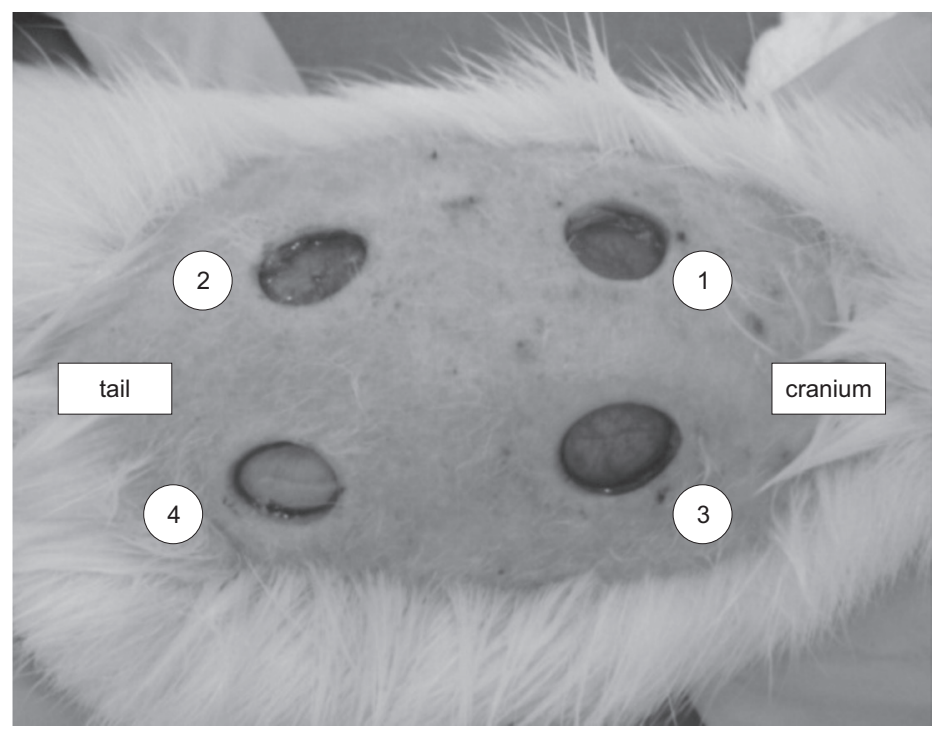

Figure 1 - Lesions on the back of animal n. $D_{0}$ 
After the excisions were made, each lesion received $0.25 \mu \mathrm{L}$ of a suspension containing $1.5 \times 10^{6} \mathrm{CFU} / \mathrm{mL}$ of $S$. aureus, to infect the aponeurotic tissue superficially. Following that, the lesions were covered with gauze and sterile dressings, and the researchers waited 24 hours to carry out a culture swab of the four lesions and to start the therapy.

The animals were assessed every 24 hours for 14 days, for clinical observation of the lesions, in relation to the presence of: adverse effects, perilesional irritation, scar retraction, and dressing the wounds, in accordance with the group's treatment. All the data was recorded in pre-established protocols.

On the $3^{\text {rd }}, 7^{\text {th }}, 11^{\text {th }}$ and $14^{\text {th }}$ post-operative days (POD) the wound areas were measured with digital calipers, and on each occasion, removing a fragment of one of the lesions for histopathological evaluation. On the last day of the experiment, all the animals were anesthetized and euthanized with thoracotomy, and cardiac puncture was undertaken, removing $4 \mathrm{ml}$ of blood for analysis of glucose, cholesterol and triglycerides, in addition to the liver, for microscopic analysis of the hepatotoxicity of the extract.

\section{Histological analysis}

All the material removed for microscopic examination was numbered, without the identification of the group to which it belonged, and was fixed using a $10 \%$ formaldehyde solution. The samples were dehydrated and diaphanized in alcohol and xylol, included and embedded in warmed paraffin. After hardening, the blocks were taken for microtomy, for the obtaining of sections of $5 \mu \mathrm{m}$, these being collected on glass slides and stained with Hemotoxylin and Eosin stain.

The analysis of the material used a reference points the inflammatory, proliferative and remodeling phases, which make up the process of healing. For analysis of the results, Table 1 was prepared, with scores based on the literature ${ }^{(5,8)}$. The intensity of the variables $(1+$ to $5+)$ was multiplied by positive or negative factors based on their importance for the healing. The sum of these products corresponded to the total score for each animal, which was later multiplied by $4(n)$.

Table 1 - Scores used for evaluation of the histopathological test

\begin{tabular}{|c|c|c|c|c|c|c|}
\hline Variables & Absent & Present & Mild & Moderate & Intense & Factor \\
\hline Scab & +1 & +2 & - & - & - & -1 \\
\hline Acute inflammation & - & - & +3 & +4 & +5 & -4 \\
\hline Chronic inflammation & - & - & +3 & +4 & +5 & +2 \\
\hline Granulation tissue & - & - & +3 & +4 & +5 & +5 \\
\hline Fibroblast proliferation & - & - & +3 & +4 & +5 & +5 \\
\hline New blood vessels & - & - & +3 & +4 & +5 & +5 \\
\hline Re-epithelialization & - & - & +3 & +4 & +5 & +5 \\
\hline Collagen fibers & +1 & +2 & - & - & - & +10 \\
\hline
\end{tabular}

\section{Statistical tests}

The data was analyzed using the program GraphPad InStat ${ }^{\circledR}$. The numerical variables were evaluated using the ANOVA test with two interaction factors, with Tukey's post-hoc test for analysis of the effect between the groups. For the non-parametric data, the Mann-Whitney test was used. The level of significance established was 5\% ( $<<0.05)$.

\section{Results}

\section{Evaluation of the antimicrobial activity and determination of the MIC}

The raw extract of the stem of $Z$. tuberculosa did not demonstrate activity for the fungus tested, but it was active against the $S$. pyogenes, $S$. aureus and $S$. epidermidis bacteria, as shown in Table 2. S. aureus was the microorganism chosen for continuation of the tests, because it is important in the occurrence of nosocomial infections, mainly in integumentary infections, as well as presenting a zone of inhibition with approximately $50 \%$ of the size of the positive control's zone of inhibition ${ }^{(9-10)}$. The extract's MIC for this microorganism was $62.5 \mu \mathrm{g} / \mathrm{mL}$.

\section{Toxicity in relation to Artemia salina (TAS)}

Following the determination of the MIC, the researchers proceeded to the TAS. According to the criteria determined in this research, the extract was shown to be atoxic in the concentrations between 100 and $10 \mu \mathrm{g} / \mathrm{mL}$. The values expressed in the MIC $(62.5$ 
$\mu \mathrm{g} / \mathrm{ml}$ ) and in this study's TAS are in consonance for safe use with this study's animals, this being legitimized by the absence of mortality among the animals during the experiment.

Table 2 - Result of disk diffusion with the raw extract of the stem of $Z$. tuberculosa for bacterial and fungal strains

\begin{tabular}{lcc}
\hline \multirow{2}{*}{ Micro-organisms } & \multicolumn{2}{c}{$\begin{array}{c}\text { Products tested/size of zone } \\
\text { of inhibition }(\mathbf{m m})\end{array}$} \\
\cline { 2 - 3 } & $\begin{array}{c}\text { Positive } \\
\text { control }\end{array}$ & Extract \\
\hline Streptococcus pyogenes & 35 & $18.6^{*}$ \\
Klebsiella pneumoniae & 30 & - \\
Escherichia coli & 32 & - \\
Pseudomonas aeruginosa & 33 & - \\
Staphylococcus epidermidis & 32 & $10^{*}$ \\
Staphylococcus aureus & 30 & $14^{*}$ \\
Proteus mirabilis & 19 & - \\
Candida albicans & 11 & - \\
\hline
\end{tabular}

(-) Did not present a zone of inhibition of growth

*Value of the mean of the triplicate

\section{Evaluation of the healing process in vivo}

During the experiment, the animals were monitored in relation to their temperature and weight, and the lesions were observed macroscopically, including the measuring of the lesions' diameters. Regarding temperature, on the day of the surgery, $\left(D_{0}\right)$ all of the animals had temperatures within the normal range of 36.2 to $37^{\circ} \mathrm{C}$. From the $3^{\text {rd }}$ to the $7^{\text {th }}$ POD, only the animals in the groups TE and NC presented rises in temperature. The animals' mean temperature varied between 36.2 and $38^{\circ} \mathrm{C}$, not showing a significant difference between the groups $(p=0.1116)$.

The animals in all the groups presented weight oscillation over the 14 days of the experiment. The mean maximum weight was 265.1 grams and the minimum, 208.4 grams. This difference was shown to be significant between the groups NC and TOE, and the groups NC and OE. However, the groups TOE, OE and PC presented a similar pattern.

It was observed that in the pre-operative period, the animals maintained a mean daily ingestion of feed of $24 \mathrm{~g} /$ day. After the undertaking of the lesions on the backs, however, there was oscillation, the mean ingestion being $18.5 \mathrm{~g} /$ day per animal.

In the evaluation of the lesions' diameters, contraction of the wounds was observed from the $3^{\text {rd }}$ POD, although the groups NC and TE did not have this characteristic. From the $7^{\text {th }}$ POD, reduction in the diameter was observed, which was accentuated on the $11^{\text {th }}$ and $14^{\text {th }}$ days. The TOE and OE groups had better responses in terms of the contraction of the wound. The highest mean over the experiment was observed in the TE group, with $7.46 \mathrm{~mm}$, and the lowest, in the TOE group, with $5.21 \mathrm{~mm}$. The Tukey test showed a significant difference between groups NC and TOE, and TE and TOE, as well as between TE and OE.

The macroscopic study allowed the researchers to observe differences between the groups regarding the lesion's color. The lesion's aspect, in relation to the color, clinically reflects the development of the healing process. Yellow coloration indicates infection. This data indicates that the groups treated with Z. tuberculosa had a smaller quantity of animals with this characteristic, showing the extract's antimicrobial activity, whether topically and/or orally. This is corroborated by the scores obtained in the histological study.

From the $11^{\text {th }}$ day onward, yellow or pink coloration was observed in $100 \%$ of the animals in the groups $\mathrm{PC}, \mathrm{TE}, \mathrm{TOE}$ and $\mathrm{OE}$, and in $75 \%$ of those in group NC, indicating that the phases of granulation and re-epithelialization had started. No animal presented brown coloration, which is an indication of cell death and necrosis.

The phlogistic signs of inflammation, such as perilesional rubor or hyperemia, edema and the presence of exsudate were not observed macroscopically in any of the groups, evidencing that the extract used in the research does not provoke irritation in the perilesional skin, or in the cutaneous lesion. This data, moreover, is corroborated by the scores obtained in the histological study.

Furthermore, macroscopically, in relation to the occurrence of granulation tissue, it was observed that on the $3^{\text {rd }}$ POD, the animals in group TE had $100 \%$ of granulation, in those in groups PC and TOE it was $75 \%$, and in those in group OE, it was 50\%. These findings confirm that group TE had the best response, which was also legitimized by the scores of the histological study.

\section{Histological evaluation of the lesions}

The histological data was collected in accordance with the phases of healing, and was organized in accordance with the scores for quantification. In Table 3 it is possible to observe that the highest means in the scores were obtained by the groups which received the extract, whether topically and/or orally. This difference was shown to be statistically significant between groups NC and TE. 
Table 3 - The scores of the histopathological study of the wounds infected by $S$. aureus

\begin{tabular}{lccccc}
\hline \multirow{2}{*}{$\begin{array}{c}\text { Post-operative } \\
\text { days }\end{array}$} & $\begin{array}{c}\text { Positive } \\
\text { control }\end{array}$ & $\begin{array}{c}\text { Negative } \\
\text { control }\end{array}$ & $\begin{array}{c}\text { Topical } \\
\text { extract }\end{array}$ & $\begin{array}{c}\text { Topical } \\
\text { and oral } \\
\text { extract }\end{array}$ & $\begin{array}{c}\text { Oral } \\
\text { extract }\end{array}$ \\
\hline $3^{\text {rd }}$ & 87 & 87 & 634 & 372 & 229 \\
$7^{\text {th }}$ & 493 & 293 & 300 & 272 & 842 \\
$11^{\text {th }}$ & 670 & 420 & 1231 & 1150 & 812 \\
$14^{\text {th }}$ & 704 & 634 & 1400 & 1004 & 1324 \\
$N_{\text {Mean }}^{*}$ & 488.5 & $358.5^{*}$ & $891.25^{*}$ & 699.5 & 801.8 \\
\hline$*_{p}<0.05$ & & & & &
\end{tabular}

The analysis of the lesions of the groups TE, TOE and OE treated with the extract of $Z$. tuberculosa evidenced important findings in the healing process, visualized in Figure 2 . On the $3^{\text {rd }}$ day, one can observe acute inflammation with presence of macrophages $(2 \mathrm{~A})$; on the $7^{\text {th }}$ day, one can identify the granulation tissue, with formation of neovascularization, collagen fibers and the start of epithelialization (2B); on the $11^{\text {th }}$ day, one can see emphasized the collagen fibers (2C).

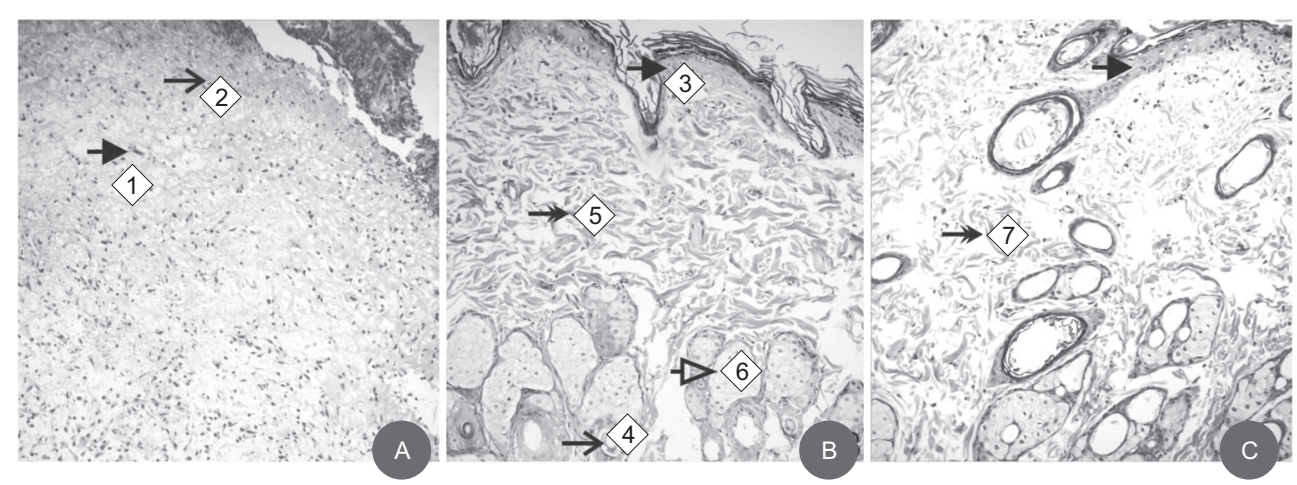

Figure 2 - (A) Photomicrography of a cutaneous wound, topical extract, $3^{\text {rd }}$ day post-surgery $\left({ }^{1}\right.$ macrophages, 2 acute inflammation); (B) Photomicrography of a cutaneous wound, topical and oral extract, $7^{\text {th }}$ day post-surgery ( ${ }^{3}$ epithelialization, ${ }^{4}$ neovascularization, ${ }^{5}$ collagen fibers, ${ }^{6}$ granulation tissue) and (C) Photomicrography of a cutaneous wound, oral extract, $11^{\text {th }}$ day post-surgery ( ${ }^{7}$ collagen fibers) (Magnification $10 \mathrm{x}, \mathrm{HE}$ )

The histological analysis of the liver showed an absence of hepatotoxicity in all the groups studied. In the biochemical evaluation, the data was not given as it presented similar parameters for cholesterol, triglycerides and glucose in all the animals in the experiment, it being impossible to establish correlations between these findings and the use of the extract of Z. tuberculosa.

\section{Discussion}

Caring for wounds should be a constant concern for the nurse, as caring for cutaneous lesions with the resources currently existing remains a challenge. In spite of the technological advances, few have access to these, due to their high cost and their limitation to the major urban centers ${ }^{(11)}$. Studies show that the use of plants is becoming a necessity for broadening the therapeutic arsenal in this area and in the reduction in the financial resources spent for the treatment ${ }^{(12)}$. In the present study, the raw ethanolic extract of $Z$. tuberculosa showed antimicrobial activity in vitro for $S$. aureus, was shown to be atoxic by the test with Artemia salina, and in vivo had a healing effect for infected excision wounds in rats, this data being promising for the continuation of studies which may elucidate the extract's mechanism of action, as this pathogen is responsible for the majority of infections of the tegumentary system, and is resistant to the majority of the antimicrobials used in clinical practice ${ }^{(10)}$.

In the in vivo experiment, the animals' temperature was little-changed, not passing $38^{\circ} \mathrm{C}$. Even with local infection, proven by the culture of the lesions, the animals did not have systemic consequences. The rise observed was due to the mechanism of healing itself, which leads to an increase in the vascularization through the local inflammatory response, thus increasing the body temperature ${ }^{(13)}$.

Checking the weight is an important nutritional parameter in various experimental studies, being related to wound healing alterations ${ }^{(14)}$. The difference in weight can be directly related to reduction in the daily ingestion of feed, as also by the daily handling, with wound dressing and biopsies undertaken on the $3^{\text {rd }}, 7^{\text {th }}$, $11^{\text {th }}$ and $14^{\text {th }}$ days. 
The association of weight loss with the inflammatory process itself was described in a study asserting that inflammation produces inflammatory cytokines and Tumor Necrosis Factor (TNF), which act as mediators of the inflammation and of the immunity(6). With the serum levels of TNF raised, there is stimulation in the production of a protein called leptin, a rise in which is related to the feeling of fullness. Increased levels of this protein induce the organism to spend energy and reduce the consumption of food, causing lack of appetite and, consequently, weight loss.

The coloring, as a parameter for evaluation of the condition of the wounds, showed that these presented clinical progression within that expected for each stage of wound healing. In the groups which were treated, there was a predominance of pink coloration, which is characteristic of epithelialization, this being the final phase of the tissue repair. This data legitimized the findings which used the barbatimão (stryphnodendron barbatimam) and Pink Ipê (tabebuia impetiginosa) cream in wounds in rats ${ }^{(15)}$ and differed from the study with gel and the glycolic extract of the leaf of the Common Guava (Psidium guajava L.) which did not observe significant difference between the groups treated and that which used saline solution ${ }^{(16)}$.

Macroscopically, the total closure of the lesions did not occur, in all the groups, over the 14 days of the experiment. There was, however, a significant reduction in the diameter in the treated animals, data confirmed by the presence of re-epithelialization in the histological samples. In animals whose skin adheres less to the deeper layers (such as rats), the contraction can reach 80 to $90 \%$ closure of cutaneous lesions ${ }^{(14)}$.

The histological analysis allows one to infer that the groups treated with the extract of $Z$. tuberculosa obtained the best results, when compared with the positive and negative control groups. This is due to the lower inflammatory reaction of the groups treated with the extract. A certain degree of inflammation is necessary, but a heightened inflammatory reaction is harmful, as there can be compromising of the microcirculation and it can also inhibit the formation of fibroblasts ${ }^{(17)}$. The literature also presents similar results with the evaluation of the effects of the topical treatment with cream with a pequi-oil base (Caryocar coriaceum Wittm)(18) and with essential oils of some species of Juniper (Juniperus) a traditional plant in folk medicine in Turkey ${ }^{(19)}$.

The biochemical values of the animals in experiments can be changed, due to the environmental conditions and the stress induced by the procedure itself ${ }^{(20)}$. The results of triglycerides, cholesterol and glucose in the animals studied had similar results to those presented in the literature.

\section{Conclusion}

The raw ethanolic extract of $Z$. tuberculosa has antimicrobial action in vitro for Streptococcus pyogenes, Staphylococcus epidermidis and Staphylococcus aureus. The groups treated with the extract had a result which was similar to that of the positive control in the process of wound healing. Histologically, the animals treated topically had a greater quantity of cells for closing the lesions. This research validates previous studies with this extract and advances by demonstrating the potential healing activity of $Z$. tuberculosa. This provides encouragement for the continuation of studies, with a view to the identification of the active ingredients which are responsible for the pharmacological activity, and its mechanism of action in the process of wound healing. This will contribute to the development of a product which may be used as an alternative in the repair of infected cutaneous wounds.

\section{References}

1. Mendonça RJ, Coutinho-Netto J. Cellular aspects of wound healing. An Bras Dermatol. 2009; 84(3):257-62.

2. Alvim NAT, Ferreira MA, Cabral IE, Almeida AJ Filho. The use of medicinal plants as a therapeutical resource: from the influences of the professional formation to the ethical and legal implications of its applicability as an extension of nursing care practice. Rev. Latino-Am. Enfermagem. 2006;14(3):316-23.

3. Pagano MC, Maria SM. Effect of Phosphorus Fertilization on Arbuscular Mycorrhizal Colonization of Zeyheria tuberculosa a Native Species in Brazil's Forest. Middle-East J Sci Res. 2010;6(6):604-11.

4. Rahmatullah $M$, Rahman MA, Haque $M Z$, Mollik $A H_{\text {, }}$ Miajee EU, Begum R, et al. A survey of medicinal plants used by folk medicinal practitioners of station purbo para village of Jamalpur Sadar Upazila in Jamalpur district, Bangladesh. Am-Eurasian J Sustain Agric. 2010;4:122-35.

5. Bastos MLA, Lima MRF, Conserva LM, Andrade VS, Rocha EM, Lemos RP. Studies on the antimicrobial activity and brine shrimp toxicity of Zeyheria tuberculosa (Vell.) Bur. (Bignoniaceae) extracts and their main constituents. Ann Clin Microbiol Antimicrob. 2009;8:1-16.

6. Vieira AP, Santos NR, Borges JHS, Vicenzi MPA, Schmitz WO. Flavonoid action in second intention 
healing in surgically-induced clean wounds in Wistar rats. Semina Cienc Biol Saude. 2008;29(1):65-74.

7. Ayres MCC, Brandão MS, Vieira-Junior GM, Menor JCAS, Silva HB, Soares MJS, et al. Antibacterial activity of useful plants and chemical constituents of the roots of Copernicia prunifera. Braz J Pharmacogn. 2008; 18(1):90-7.

8. Medeiros AC, Ramos AMO, Dantas Filho AM, Azevedo RCF, Araujo FLFB. Topic treatment of rat burns with hyaluronic acid. Acta Cir Bras. [Internet]. 1999 [acesso 8 jun 2012];14(4). Disponível em: http://www.scielo.br/ scielo.php?script=sci_arttext\&pid=S0102-86501999000 400010\&Ing=en\&nrm=iso

09. Vitorino Filho RNL, Batista MCS, Verçosa BLA, Silva SMMS, Bonfim JM, Brandão AAC, et al. Avaliação do uso de pomada à base de sementes de jaqueira (Artocarpus heterophyllus Lam) na terapêutica tópica de feridas. J Basic Appl Pharm Sci. 2007;28(3):279-86.

10. Moura JP, Pimenta FC, Hayashida M, Cruz EDA, Canini SRMS, Gir E. Colonization of Nursing Professionals by Staphylococcus aureus. Rev. Latino-Am. Enfermagem. 2011;19(2):325-31.

11. Lima ACB, Guerra DM. Avaliação do custo do tratamento de úlceras por pressão em pacientes hospitalizados usando curativos industrializados. Ciênc Saúde Coletiva. 2011;16(1):267-77.

12. Majewska I, Gendaszewska-Darmach E. Proangiogenic activity of plant extracts in accelerating wound healing - a new face of old phytomedicines. Acta Biochim Pol. 2011;58(4):449-60.

13. Carvalho LH Júnior, Santos RL, Mendonça CJA, Campos CT, Andrade MAP. Evalution of skin temperature, reactive $\mathrm{C}$ protein, and hemosedimentation speed variation in uncomplicated primary knee total arthroplasty. Acta Ortop Bras. 2006;14(3):161-4.

14. Ono MCC. Influência de dieta imunomoduladora na cicatrização cutânea em ratos [dissertação de mestrado]. Santa Catarina (PA): Universidade Federal do Paraná; 2009. 15. Coelho JM, Antoniolli AB, Silva DN, Carvalho TMMB, Pontes ERJC, Odashiro AN. Effects of silver sulfadiazine, ipê roxo (Tabebuia avellanedae) extract and barbatimão (stryphnodendron adstringens) extract on cutaneous wound healing in rats. Rev Col Bras Cir. 2010;37(1):45-51.

16. Okamoto $\mathrm{MKH}$. Estudo das atividades cicatrizante e antimicrobiana do extrato glicólico e gel de Psidium guajava L. e estudo da estabilidade do gel [tese de doutorado]. São Paulo (SP): Faculdade de Ciências Farmacêuticas da Universidade de São Paulo; 2010.

17. Lucena PLH, Ribas Filho JM, Mazza M, Czeczko NG, Dietz UA, Correa Neto MA, et al. Evaluation of the aroreira (Schinus terebinthifolius Raddi) in the healing process of surgical incision in the bladder of rats. Acta Cir Bras. 2006;21(2):46-51.

18. Batista JS, Silva AE, Rodrigues CMF, Costa KMFM, Oliveira AF, Paiva ES, et al. Avaliação da atividade cicatrizante do óleo de pequi (caryocar coriaceum wittm) em feridas cutâneas produzidas experimentalmente em ratos. Arq Inst Biol. 2010;77(3):441-7.

19. Tumem I, Suntar I, Keles H, Küpeli AE. A therapeutic approach for wound healing by using essential oils of cupressus and juniperus species growing in Turkey. Evid Based Complement Alternat Med. [Internet]. 2012 [acesso 9 dez 2012]; 2012. Disponível em: http:// www.hindawi.com/journals/ecam/2012/728281/abs/ doi: $10.1155 / 2012 / 728281$

20. Dantas JA, Ambiel CR, Cuman RKN, Baroni S, Amador $\mathrm{CAB}$. Valores de referência de alguns parâmetros fisiológicos de ratos do Biotério Central da Universidade Estadual de Maringá, Estado do Paraná. Acta Sci Health Sci. 2006;28(2):165-70.

\section{Erratum}

\section{Issue v22n1, page 165}

For

Patrícia de Albuquerque Sarmento ${ }^{2}$

Terezinha da Rocha Ataíde ${ }^{3}$

Ana Paula de Souza e Pinto ${ }^{4}$

João Xavier de Araújo-Júnior ${ }^{5}$

Ingrid Martins Leite Lúcio ${ }^{6}$

Maria Lysete de Assis Bastos ${ }^{6}$

Read

Patrícia de Albuquerque Sarmento ${ }^{2}$

Terezinha da Rocha Ataíde 3

Ana Paula Fernandes Barbosa ${ }^{4}$

João Xavier de Araújo-Júnior ${ }^{5}$

Ingrid Martins Leite Lúcio ${ }^{6}$

Maria Lysete de Assis Bastos ${ }^{6}$ 